\title{
A FERTILE SOIL? \\ Indonesia and Islamic Fundamentalism
}

\author{
Abdul Gaffar Karim \\ Gadjah Mada University
}

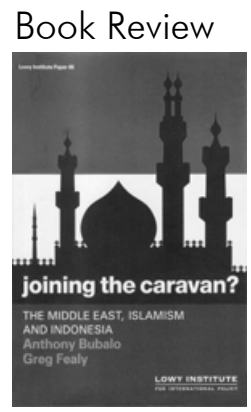

$$
\begin{aligned}
& \text { Book title : Joining the caravan? The Middle east, Islamism } \\
& \text { and Indonesia } \\
& \text { Author : Anthony Bubalo and Greg Fealy } \\
& \text { No. of Pages : } \quad \text { xxii }+128 \\
& \text { Year : } 2005 \\
& \text { Publisher : Lowy Institute for International Policy, } \\
& \text { Sydney } \\
& \text { Website : http://www.lowyinstitute.org/Publicatio } \\
& \text { nGet.asp?i=229 }
\end{aligned}
$$

One day I attended a forum on religious dialogue in Canberra. As a Muslim, I was asked many kinds of question by my fellow Australians from different religious backgrounds. Some questions had very clear 'yes' or 'no' answers; such as “do you shake hand, even women's hands?" (my answer was yes), or "do you drink alcohol" (my answer was no). Other questions, however, required more elaborated answers, such as "do you always agree with what the Mufti says?" By the Mufti they meant the then-Australian Mufti Sheikh Tajuddin al-Hillali. To such a question, I had to explain a bit longer that the Mufti structure was actually unfamiliar for Muslims with sunni background like me, so that it wouldn't matter whether or not I agreed with the Mufti because I never needed someone to make statements on my behalf as a Muslim who lived in Australia.

The most difficult questions to answer, I must admit, were the ones related to terrorism issues. One of other attendees asked this question: "Do you know the Cleric who was released from the prison last year?" 
"Do you mean Abubakar Ba'asyir?" I asked him.

"Yes," he replied. "I understand that he is a leader of an educational institution named pesantren. Why do you think such an educational institution would teach radicalism and support terrorism?"

I was glad to have an opportunity to clarify such an issue. I have to say, however, that this was really a difficult question. I had learned that terrorism was a big issue in Australia. From my experience I understood that many Australians would expect you to condemn terrorists and terrorism acts, especially those that claimed the life of Australians such as the Bali bombings. In answering my fellow attendee's question, I avoided saying anything too specifically about Abubakar Ba'asyir, considering the sensitivity of the issue. What I did to answer his question was explaining to him the broader context of the pesantren and the social features of Muslims in Indonesia. My intention was to give him a wider and clearer picture, so that he would be able to locate the answer of his question himself.

Despite the more careful answer I gave to my group mate in Canberra, the conversation itself led me to thinking about how deep the misunderstanding about Muslim communities (particularly Indonesian Muslims) really is these days. I understand that this is not an isolated symptom. Rather, it is part of more global phenomenon. Since the so-called 911 terrorist attack in 2001, international relationship has reshaped, with the US keeps trying to bring the whole world into its side on what it calls the war against terrorism. In Southeast Asian context, the Bali bombing on 12 October 2002 has also given the global war against terror a deepened regional context.

The misunderstanding about Muslim communities seems to be stronger amongst the not-very-informed people, but not limited to them. The more educated and informed people may also develop misunderstanding with regards to the nature of Indonesian Muslim communities and their relation with global Islamic ideas and movements. The book Joining the Caravan? written by Anthony Bubalo and Greg Fealy that we are discussing here has correctly pointed at the lack of understanding amongst so many people that Islam is not a monolithic ideological movement cantered in the Middle East. Although there are some connections between Indonesian Islam and the Middle East, the adoption of the ideas and methods of movement to Muslim communities in this country has also intertwined with local factors, and lead to the diversity of Islamic ideas and movement in 
Indonesia. Even amongst the 'fundamentalist Muslim groups' (however the term is debatable) themselves, diversity do exist.

The title of this book is inspired by a polemic written by Palestinian Islamist Abdullah Azzam in 1987 entitled Ilhaq bil-Qaafila (Join the Caravan), and intended to address the misperception that "Islamism is today a monolithic ideological movement spreading from its putative centre, the Middle East, to Muslim countries around the world... [or]... that Islamists around the world are fellow travellers in a global, ideological or fundamentalist caravan" (p. 5).

This book consists of six chapters, including the introduction chapter and conclusion and policy recommendation. The main chapters (one to four) are basically two sections of discussions. In the first section that comprises chapters 1 and 2, the authors dedicate the discussion to the background of the development of fundamentalist ideas and movements in a global context. The second section that comprises chapters 3 and 4 is aimed to analyse the transformation of Islamist ideas from Middle East to Indonesia, and how that impacted upon the Indonesian Muslim communities.

Chapter 1 basically tries to explain how Islam as a religion has been transferred into an ideology known as Islamism. The chapter mainly argues that Islamism was formed through a belief of comprehendsiveness of Islam in a sense that the religious teaching also covers the political, social, and economic life. "Historically, the major consequence of such a view has been the Islamist's belief in the need for an Islamic state or system" (p. 9). In discussing these issues, this chapter addresses some key terms that would later frame the analyses of Islamism in Indonesia, including the Salafiya movement, Wabhabism and Jihad. The authors trace back to the Muslim revivalist movements led by Muhamamd Ibnu Abdul Wahhab in eighteenth century and by Jamaluddin al Afghani, Muhammad Abduh and Rashid Rida in nineteenth and twentieth centuries. They also underline the Muslim Brotherhood movement initiated by Hasan al Banna and, subsequently led by Sayyid Qutb, in Egypt. The chapter is concluded by a discussion on the various meanings of Jihad, ranging from the missionary activities to holy war movement.

How the Islamists achieved political roles and dominance later in twentieth century in some states like Egypt, Algeria and Afghanistan, and how the achievements declined sharply in 1990s is discussed in chapter 2. Bubalo and Fealy underline that some failures faced by 
political Islam since 1990s was responded by two different reorientation. Some groups chose the political normalisation and accommodation with the state. This option is normally chosen by those who have strong roots and linkages in their societies, and take the local criticism and their domestic constituencies seriously. This strategy is employed by Hizb al-Wasat in Egypt, and Harakat al-Nahda and Movement for National Reform in Algeria. Other groups, however, chose to adopt more conservative, literalist view on Islam as well as more supranational approach in achieving the goals, and harden view on Islamism. Borrowing the term coined by Olivier Roy, Bubalo and Fealy call these groups 'neo-fundamentalist', "whose activism ranges from the reform of religious practices (salafism) to, in extreme cases, ultra violent terrorism (jihadist-salafism)" (p. 30). In purely supranational strategies without extremist methods involved, Hizb atTahrir is one example of this group. In a much more violent-manner, Al Qaeda is certainly the most popular part of this cluster.

In chapter 3, Bubalo and Fealy look at how Islamic fundamentalism was brought and spread in Indonesia. Unsurprisingly the chapter emphasises that:

On the one hand, Indonesians seek knowledge and inspiration from the Middle East, but on the other hand, apply this knowledge in a distinctively 'local' way....

Indonesian Islam is still regarded as predominantly tolerant and pluralistic, but the emergence in recent years of local paramilitary jihadist and terrorist groups has led to concern over perceived radicalisation and the eroding of the country's essentially 'moderate' Islamic character. (p. 47-8)

There are three elements of the spread of religious radicalism in Indonesian Islam discussed in this chapter, namely (1) the human movements, ranging from study and scholarly activities to participation of jihadist in Afghan war, (2) the Middle East (particularly the Wahhabist Saudi Arabia) Islamic propagation in Indonesia, and (3) print and internet publication on religious issues both at local and international context. ${ }^{1}$ The strength of this chapter lies in its detailed analyses (where key persons and institutions are clearly mapped out) of

\footnotetext{
1 The internet publication on the spread of religious radicalism has been analysed in more details in Merlyna Lim, Islamic radicalism and the anti-Americanism in Indonesia: the role of internet, (Washington: East West Center, 2005).
} 
the three elements that enable the reader to comprehend the complexity of the problems of religious radicalism in Indonesia. It is, however, not an introductory description so as to help beginners to study current situation of Indonesian Islam.

Impact of the above three elements on Indonesian Muslim communities is discussed in chapter 4, where the authors interestingly quote what an Indonesian salafist said: 'every seeds you plant in Indonesia grows'. This chapter is generally aimed to show that Indonesia is a fertile social ground for the growth of various ideas, including (but not exclusively) the Islamic radicalism. Three broad intellectual currents in Indonesian Islam are scrutinised in this chapter: the Muslim Brotherhood, and two main manifestations of neofundamentalism, namely Salafism and jihadist Salafism. The chapter underlines some facts in recent Indonesian development that "growing frustration and disillusionment with both Soeharto regime's treatment of Islamic organisations and the behaviour of Muslim leaders themselves" (p. 66) had lead to the search of new models for Islamic movement in Indonesia, where some elements of Muslim groups found it in the Brotherhood Movement. Aspects of the Brotherhood Movement (including the ideas and organisational methods) are adopted as solutions for the perceived problems of Indonesian Muslims. Recent social and political characteristics of Indonesian Muslim groups have the roots in this process. The more radical manifestation of neo-fundamentalism-that popularly would be addressed to as the terrorist groups-is also depicted in the later part of this chapter.

Finally, the most important contribution of this book for both academics and policy makers should be found in its last chapter, where the authors formulated six policy recommendations. First, although the global dimensions of contemporary religious-related problems (such as terrorism) are important, but it is also imperative that policy makers do not lose sight of the complex local causes.

Second, policy makers should not look at Indonesian Muslims as monolithic, or that they can simply be handled in radical-and-moderate category. It is really important to understand the complexities of social characteristics of Indonesian Islam so as to avoid reductionist approach in handling the problems.

Third, related to the non-monolithic nature of Muslims, it is important that policy makers pave the way for dialogues with a broader 
range of Islamist views. This is essential to break the misconception among the groups, also between Islam and the West.

Fourth, it is very important for policy makers to think about education and 'war of ideas' in broad terms. There is a huge need of fighting terrorisms and terrorists groups on the one hand, and fixing the ideas that underpin the radical movements on the other. However, the authors also urge Western government to stay away out of Islamic education in Indonesia because it can be seen as interference and Western efforts to dilute Islam.

Fifth, policy makers need to encourage transparency in the support of religious propagation, particularly from the Wahhabist state Saudi Arabia. Trying to minimise supports from Saudi Arabia to Indonesian Islamic education and propagation institutions would be a counterproductive to the efforts to reduce radicalism because it may make legitimate and non-jihadist institutions suffer, and potentially encourage peaceful groups to seek support from more militant financiers.

And sixth, policy makers, particularly from the Western states, needs to accept that the implementation of democracy in some countries could result in the victory of Islamist groups. The Western government should avoid the double standard where the push for the implementation of democracy in Muslim countries on the one hand, but opposed the result of the democratic process if Islamist (radical) groups gain victories in it.

In sum, this book provides balanced analyses of the growth of Islamic radicalism in Indonesia, and gives some significant insight of the international context. This book would be useful for those who want to understand the current situation of Indonesian Islam, and for policy makers who want to make the right decision in dealing with Indonesian Islam in particular, and Islam internationally in general. I believe that translation of this book in Indonesian will be of importance because so many Indonesian Muslims, as well as Indonesian government, may not really familiar with some aspects of Muslim groups in Indonesia that are discussed in this book.] 